\title{
Psychometrics of Tourism: A (de)Builder of Quality of Life? Evidence from the Model of Happiness in Dominican Republic
}

\section{Psicometría del Turismo: ¿Un (de) Constructor de la Calidad De Vida? Evidencia Empírica a Partir del Modelo de Felicidad en República Dominicana}

\author{
Miguel Puig-Cabrera \\ miguelpuig@docente.utesa.edu (10000-0003-4524-9830 \\ Universidad Tecnológica de Santiago. Postgraduate School. \\ Estrella Sadhalá Avenue, 51000, Dominican Republic.
}

\section{INFO ARTÍCULO}

Received: 6-12-2020

Revised: 24-01-2021

Accepted: 25-01-2021

\section{KEYWORDS}

\section{Tourism}

Quality of life

Dominican Republic

Small island developing state

PLS-SEM

\begin{abstract}
For small island developing states (SIDS), tourism is often seen as a passport to development and wellbeing. The happiness phenomenon among residents of tourism destinations is usually linked to the concept of quality of life (QoL).

The happiness literature suggests that there is a positive correlation between happiness and income of residents in SIDS, but there is not a clear directionality. In this correlation a large impact of non-income factors linked to wellbeing, such as own feelings and attitudes, belonging feeling to a community, identification with cultural and natural heritage, or a fair government that fulfills residents' needs.

Thus, the goal of this research is to uncover the Caribbean model of happiness according to the relationship between tourism and wellbeing in a SIDS.

To test this hypothetical-conceptual model of this work, a questionnaire was administered to obtain suitable data for measuring the quality of life based on a total of five constructs and 27 indicators among residents directly involved in the tourism activity. Partial Least Square-Structural Equation Model (PLS-SEM) was the technique used to test this hypothetical conceptual model.

This work bring empirical evidence to the happiness literature deepening in the model of wellbeing Dominican Republic characterized by three maxims: 1) the Dominican model of individual happiness is not based on material goods but emotions, and thus, greed is considered a poverty condition among rich people; 2 ) having more is having more to share with and 3) the public sector continues to be the object of mistrust among Dominican population, without covering their expectations in terms of justice administration or reliability on political leaders, despite perceiving the political environment as stable.
\end{abstract}

\section{RESUMEN}

Para los Pequeños Estados Insulares en Desarrollo (PEID), el turismo a menudo se considera un pasaporte para el desarrollo y el bienestar. El fenómeno de la felicidad entre los residentes de los destinos turísticos suele estar ligado al concepto de calidad de vida (CV).

La literatura sobre felicidad sugiere que existe una correlación positiva entre la felicidad y los ingresos de los residentes en SIDS, pero no existe una direccionalidad clara. En esta correlación existe un significativo número de factores ligados al bienestar, como sentimientos y actitudes propias, sentimiento de pertenencia a una comunidad, identificación con el patrimonio cultural y natural, o un gobierno justo que satisfaga las necesidades de los residentes. 


\begin{abstract}
Así, el objetivo de esta investigación es revelar el modelo caribeño de felicidad a partir de la relación entre turismo y bienestar en un PEID.

Para probar este modelo hipotético-conceptual, se administró un cuestionario para obtener datos adecuados para medir la calidad de vida en base a un total de cinco constructos y 27 indicadores entre residentes directamente involucrados en la actividad turística. La técnica de Ecuaciones Estructural de Mínimos Cuadrados Parciales (PLS-SEM) fue utilizada para probar este modelo hipotético-conceptual.

Este trabajo aporta evidencia empírica a la literatura sobre la felicidad profundizando en el modelo de bienestar de República Dominicana caracterizado por tres máximas: 1) el modelo dominicano de felicidad individual no se basa en bienes materiales, sino en emociones, por lo que la codicia es considerada una condición de pobreza entre las personas de clase alta; 2) tener más es tener más para compartir y 3) el sector público sigue siendo objeto de desconfianza entre la población dominicana, sin cubrir sus expectativas en cuanto a la administración de justicia o la confiabilidad de los líderes políticos, a pesar de percibir el entorno político como estable.
\end{abstract}

\title{
1. INTRODUCTION
}

For small island developing states (SIDS), tourism is often seen as a passport to development and wellbeing. Several case studies focus on small island destinations (Uysal \& Modica, 2016) to analyze this binomial: Aruba (Croes et al., 2011); Malta (Croes et al.) Mauritius (Sharpley \& Naidoo, 2010; Sharpley \& Naidoo, 2016); Fiji (Pratt et al., 2016); Sitka in Alaska (Vogt et al., 2016); Magnetic Island (Pearce et al., 1996) and Palma de Mallorca, Spain (Nawjin \& Mitkas, 2012).

The happiness phenomenon among residents of tourism destinations is usually linked to the concept of quality of life (QoL) (Ridderstaat et al., 2016). According to the concept of QoL of The World Health, it defines as "individual perceptions of their position in life in the context of the culture and value systems in which they live and about their goals, expectations, standards, and concerns. It is a broad-ranging concept affected in a complex way by the person's physical health, psychological state, level of independence, social relationships, and their relationships to salient features of their environment".

The happiness literature suggests that there is a positive correlation between happiness and income of residents in SIDS, but there is not a clear directionality (Rivera et al., 2016). In this correlation a large impact of non-income factors linked to wellbeing (Kafashpor et al., 2018), such as own feelings and attitudes, belonging feeling to a community, identification with cultural and natural heritage, or a fair government that fulfills residents' needs.

On the other hand, some authors analyze the "false happiness" commodificated as a means to attract tourism and justifying and further entrenching objective economic inequalities (Phillips et al., 2021).

QoL models include in general a total of five dimensions (Andereck \& Nyaupane, 2011; Kim et al., 2013): material wellbeing; emotional wellbeing; community wellbeing; cultural and natural heritage-based wellbeing, and government wellbeing.

Material wellbeing includes everything related to the material needs of the individual, encompassing any tangible goods that the individual considers fundamental to maintain his existence (Millán-Puelles, 1962): food, clothing, housing, normal and luxury goods

Emotional wellbeing is "the ability to think, learn, and understand one's emotions and the reactions of others. It is a state of balance, both within and with the environment. Physical, psychological, social, cultural, spiritual, and other interrelated factors participate in producing this balance" (WHO, 2013:1).

Community wellbeing is the collective perception about all the dimensions contained in the concept of QoL, including factors such as lifestyles, environment, socioeconomic situation, cultural and natural resources, political situation, among others (Smith \& Reisinger, 2013).

Cultural and natural heritage-based wellbeing is based on the construction of a common identity made by the relation of the community members with these resources as well as the interrelations made by members concerning these very resources (Landorf, 2009).

Government wellbeing is the relation that a community has with the political leaders, as well as the perception of the political decisions on the QoL among the members of the community (Fritjers et al., 2020). 
Thus, the goal of this research is to uncover the Caribbean model of happiness according to the relationship between tourism and wellbeing in a SIDS. This implies measuring the perception of people involved in tourism activity concerning five wellbeing dimensions: material, emotional, community, cultural and natural heritage-based, and governmental.

The case study of this research focuses on Dominican Republic, one of the leading destinations in the Caribbean. This SIDS is characterized by being a focus with high levels of poverty and tourism development coexisting. With a concentration of $20 \%$ of tourists visiting the Caribbean, this island received 6.5 million tourists in 2019 ( $+6.2 \%$ more than the previous year). Despite this, poverty affected 30\% of the Dominican population in that year (ONE, 2020).

The methodology of this work consists of identifying and measuring the existing constructs in the Caribbean model of happiness reported by the relationship between tourism and wellbeing. Partial Least Square-Structural Equation Model (PLS-SEM) (Hair et al., 2016) was the technique used to test this hypothetical conceptual model.

This work brings empirical evidence to the happiness literature deepening in the model of wellbeing Dominican Republic. The findings suggest that the Dominican model of happiness is characterized by three maxims: 1) Materialism does not buy happiness and good emotions; 2) The measure of who we are is what we do with what we have; and 3) The care of human life and happiness should be the only object of good government.

After this introduction, there is a literature review, together with a presentation of the hypotheses to be tested. The third section describes the data collection and the methods used to carry out the PLS-SEM analysis. The fourth section contains the findings of the analysis as well as the discussion of these findings. Finally, a set of conclusions is provided in the fifth section.

\section{THEORETICAL BACKGROUND AND HYPOTHESES DEVELOPMENT}

\subsection{The relationship between material and emotional wellbeing dimensions}

In the Global North countries, happiness is related to material consumption. This is because the material norms on which judgments of well-being are based increase in the same proportion as the actual income of the society (Easterlin, 1995).

Material wellbeing (M-WELLB) and emotional wellbeing (E-WELLB) have been deeply analyzed in literature and there is no consensus about the prediction power between one variable on the other (Bedran-Martins \& Philippi, 2018; Cho, 2018; Sarriera et al., 2015).

Kahneman \& Deaton (2010) based on a sample of 450,000 responses in the USA to test that material wellbeing improves evaluation of life but does not buy happiness and low income is associated both with low life evaluation and low emotional well-being.

However, Gross-Manos (2017) suggests that material wellbeing has a direct effect on emotional wellbeing and the same power regardless of the income level of the countries.

From the Global South point of view, there is evidence that the so-called gross national happiness (Di Tella \& MacCulloch, 2008) does not depend on material wellbeing.

Siddiqi (2004) describes the example of material well-being in a Bangladeshi community as the one in which "'bhat, kapor or shonman niye shukhey thakbo" (we live in happiness with rice, clothes, and respect) (White, 2010). Another similar case occurs in Bhutan, despite the high level of malnutrition and energy poverty at the national level, the study by Biswas-Diener et al. (2015) reported cases of satisfaction much higher than what could be expected.

On the other hand, Cohen et al. (2020) give empirical evidence based on a case study for young black women living in Soweto (South Africa) concluding that material wellbeing is a key issue that needs to be enhanced so that emotional wellbeing also increases as a result. 
In a case study such as Brazil, anti-poverty programs are focused on fostering both material and emotional wellbeing simultaneously (Bedran-Martins \& Philippi, 2018).

It is a fact that any human being has a series of minimum prerequisites of material wellbeing that households and societies require for overcoming poverty and supporting a decent life for all (Rao \& Min, 2018). However, contrasting global north and south points of view, the power of prediction of material wellbeing over emotional wellbeing is more diffuse.

Phillips et al. (2021) analyze the effects of the international Bulanaires campaign in Fiji as an example of false non-material happiness as a means to attracting international tourism, commodificating wellbeing and justifying and further entrenching objective economic inequalities.

The $\mathrm{H} 1$ of this research tests the existence of a relationship between M-WELLB and E-WELLB, as well as the power and directionality of this relationship:

\section{H1: Material and Emotional dimensions of wellbeing have a significant and direct relationship}

Finally, the current political situation, as well as the (in)accessibility to public benefits and services, seems to deteriorate the emotional wellbeing of the population. Thus, $\mathrm{H} 4(\beta=-0.299, \rho=0.002)$ is unsupported.

\subsection{The relationship between Material and Community Wellbeing dimensions}

Regardless of M-WELLB can be a predictor of E-WELLB at the individual level, this relation differs concerning community or collective wellbeing (COM-WELLB).

According to Lee \& Kim (2016), COM-WELLB can be understood as "a geographically bounded group of people at a local scale, usually residents in a locality, who are subject to direct or indirect interaction with one another". From this point of view, wellbeing is a means of territorialization of interests that priories the interests at a scale of a community as opposed to individual, national or international scales (Atkinson et al., 2020).

Gillam \& Charles (2019) studied the case of Vila dos Pescadores (Brazil) where a community association was made as a means of guarantying basic material needs are covered such as having an income source, housing, or sanitation, among others.

Holmes \& McKenzie (2019) suggest that social or community happiness increases by redistributing material resources in such a way that social inequalities are reduced gradually until they disappear.

$\mathrm{H} 1$ described in the previous section suggested some study cases based on one of the six principles of Gandhian economics: aparigraha (non-possession) (Basole, 2005).

Regarding a community, the aparigraha principle turns to the contrary to the individual's application. The material dimension becomes important concerning a collective as a means to achieve a common series of wellbeing goals. Thus, the abundance of material resources can be a potential way to promote the wellbeing of the community when these goods are shared, without the need of eliminating the property rights or sharing all the resources (Cloutier et al., 2019).

The $\mathrm{H} 2$ of this research tests the existence of a relationship between M-WELLB and COM-WELLB, as well as the power and directionality of this relationship:

H2: Material and Community dimensions of wellbeing have a significant and direct relationship

\subsection{The relationship between Community and Cultural and Natural heritage-based dimensions of wellbeing}

$\mathrm{H} 2$ suggests that COM-WELLB is linked to shared material resources. In this case, cultural and natural resources turn into a series of tangible and intangible assets contained in the identity signs of a community 
(Palmer, 1999) that can also be managed to make community benefits (Chan et al., 2019; Gollan et al., 2019). This is the cultural and natural heritage-based wellbeing (CN-WELLB).

Power and Smyth (2016) found that sharing the heritage products with others benefits the members of a community fostering personal enrichment, social learning, and less anxiety about the present.

On the other hand, Su et al. (2016) give empirical evidence about the case of Mount Sanqingshan World Heritage Site (China), where villagers manage and take profit from heritage with negative effects on neighborhoods and thus, making conflicts among community members.

When local traditions are mercantilized and exploited, heritage can become a means to ameliorate community wellbeing, as Naidoo \& Sharpley (2016) found in the case study of Mauritius Islands. Buzinde et al. (2014) describe the case of the Masai tribes in Tanzania whose perception of tourism development is negative when involving external stakeholders. This is due to the excess of environmental conservation policies imposed by public authorities, causing the number of animal species to increase considerably, and generating significant losses for these communities (invasion of farms, loss of livestock, deterioration of crops, deaths, etc.).

To synthesize, Landorf (2009) claims that sharing and managing a common heritage is a key nexus among community members, regardless of the uses that these resources are having and the effects on the community.

The $\mathrm{H} 3$ of this research tests the existence of a relationship between COM-WELLB and CN-WELLB, as well as the power and directionality of this relationship:

H3: Community and Cultural and Natural heritage-based dimensions of wellbeing have a significant and direct relationship

\subsection{The relationship between Government and Emotional dimensions of wellbeing}

The role of the government is key in the distribution of basic and equitable needs to its community, such as health and safety, this is known as government wellbeing (G-WELLB).

The services provided by municipal authorities are a concern for residents, as a lack of transparency or accountability are challenges facing the administration. In Asian countries, a common problem is the lack of transparency and accountability of public administration (Bennett \& Dearden, 2014; Kim, 2008). Also, poverty is exacerbated by limited access to basic services, poor housing, limited employment opportunities, or inadequate infrastructure. However, some countries prosper despite corruption (Li \& Wu, 2010). Other reasons linked to the emotional well-being of residents are the abuse of human rights or the violation of labor rights (Papathanassis et al., 2018; Ram, 2018).

To conclude, the role of the government is supposed to be linked to emotional wellbeing (Atkinson \& Joyce, 2011; Fritjers et al., 2020), as public wellbeing is the sum of each individual's needs fulfilled.

The $\mathrm{H} 4$ of this research suggests the existence of a direct relationship between E-WELLB and G-WELLB:

H4: Government and Emotional dimensions of wellbeing have a significant and direct relationship

\section{RESEARCH METHOD}

The main goal of this research consists of uncovering the Caribbean model of happiness according to the relationship between tourism and wellbeing in a SIDS. This implies testing a hypothetical conceptual model has been developed according to the perception of the population directly involved in the tourism sector concerning the quality of life that this sector brings to about five wellbeing dimensions: 1) M-WELLB; 2) E-WELLB; 3) CN-WELLB; 4) COM-WELLB; and 5) G-WELLB. 
To measure tourism and quality of life relationship, a total of five constructs have been analyzed according to literature review (Carneiro et al., 2018; Kim et al., 2013; Mathew \& Sreejesh, 2017; Naidoo \& Sharpley, 2016; Uysal et al., 2016): 1) M-WELLB; 2) E-WELLB; 3) CN-WELLB; 4) COM-WELLB; and 5) G-WELLB.

Partial Least Square-Structural Equation Model (PLS-SEM) (Hair et al., 2016) was the technique used to test this hypothetical conceptual model. This is one of the most accepted techniques in theory building (Carneiro et al., 2018; Hair et al., 2011), as it analyzes the cause-effect relations between latent constructs that measure theoretical concepts through proxy variables. However, although the PLS-SEM algorithms contribute to building theoretical concepts, it is not the concept itself (Rigdon, 2012). Thus, the results of this technique can be useful as a complement to theory, but not as a substitute for existing theoretical concepts.

The case of study of this research focuses on the population directly involved in the tourism sector in Dominican Republic.

Data collection was based on fieldwork with a total of 287 questionnaires applied during the period January-May 2019.

\subsection{Study area}

This research was carried out in Dominican Republic, a Small Island Developing State that is one of the leading destinations in the Caribbean, with a concentration of $20 \%$ of the tourism in the whole region and 6.5 million tourists in the year 2018 (UNWTO, 2019).

A total of 10 tourists places (Figure 1) were visited along with the country during the period January-May 2019 to apply the questionnaires of this research, combining both natural (Isla Cabritos National Park; Monte Cristi National Park; Laguna de Oviedo; Saltos de Damajagua) and sun-and-sea tourism based destinations (Bahía de las Águilas; Boca Chica; Cabarete; Juan Dolio; Punta Cana), as well as cultural tourism-based areas (Colonial Zone in Santo Domingo).

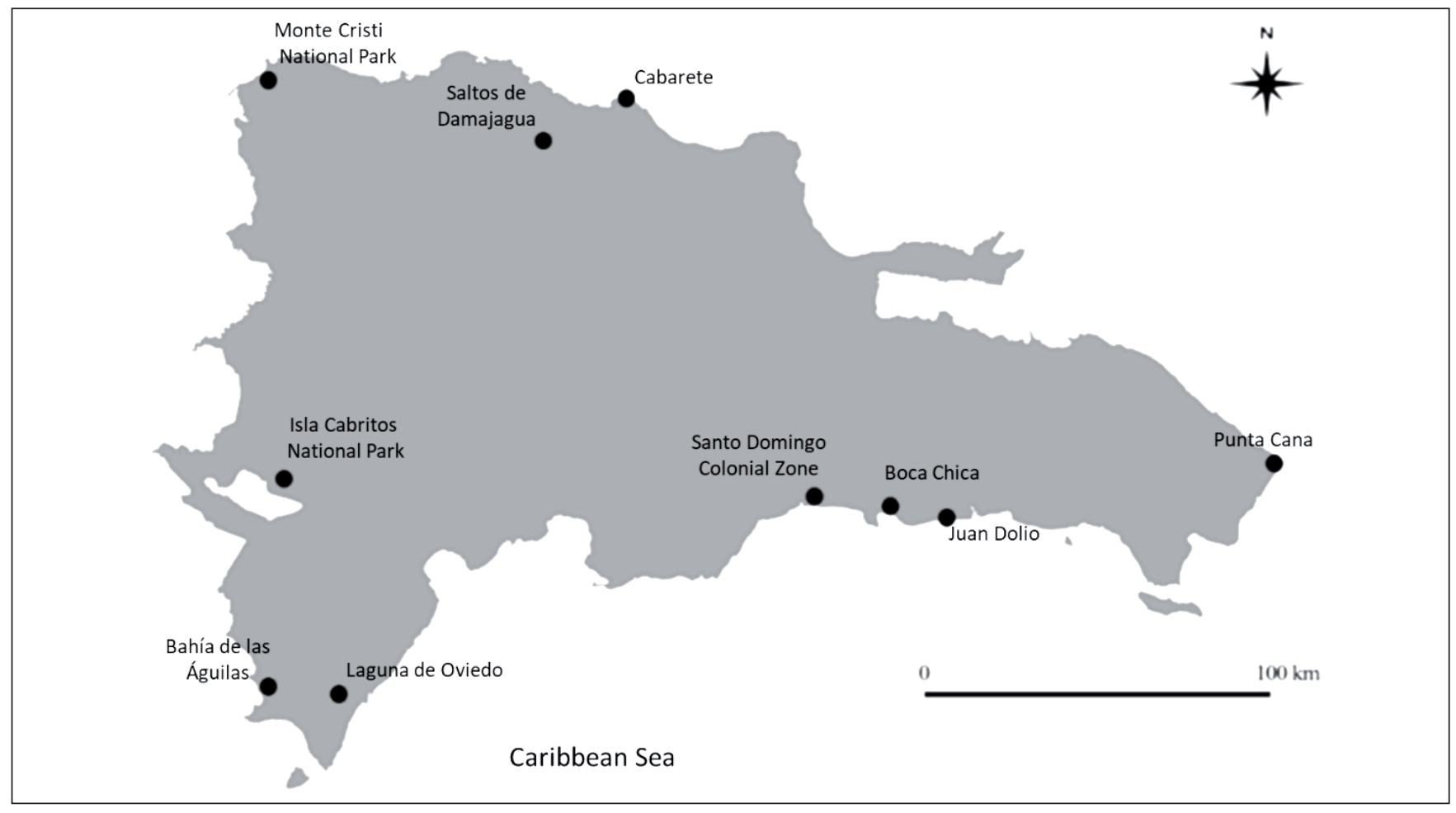

Figure 1. Study Area. 


\subsection{Data collection and sample data}

To test the hypothetical-conceptual model of this work, a questionnaire was administered to obtain suitable data for measuring the quality of life based on a total of five constructs and 27 indicators among Dominican residents directly involved in the tourism activity.

This questionnaire was designed regarding literature about tourism and quality of life: 1) M-WELLB; 2) E-WELLB; 3) CN-WELLB; 4) COM-WELLB; and 5) G-WELLB.

M-WELLB addresses issues related to the impact of tourism on material goods (Carneiro et al., 2018; Kim et al., 2013) held by people involved in the tourism sector (clothing, food, housing, others). This construct contains a total of eight indicators, including matters such as the increase of prices in the general cost of living including food, clothes, and housing due to tourism development; stability of the job; as well as the acquisition of skills and abilities in the job to get positions of greater responsibility in the future.

E-WELLB refers to the emotional situation (Mathew \& Sreejesh, 2017; Uysal et al., 2016) that tourism reports to the tourist employees (access to a decent standard of living, enjoyment of free time, stress or depression, sleep hours, others). This dimension is measured through six indicators focused on: the access to a decent living standard; the comparison of own living standard with other's; the quality and diversification of free time and leisure choices to the population in the destination; as well as the feeling of having the opportunity to start or continue studies.

COM-WELLB (Aref, 2011; Kim et al., 2013; Mathew \& Sreejesh, 2017) covers the impact of tourism at the community level (transport infrastructure, jobs, and other benefits in the environment). This construct is measured according to three indicators that focus on: increase of local entrepreneurship due to tourism; perceived effects of tourism on transport and service infrastructure; as well as generated opportunities of tourism among community members.

CN-WELLB focuses on the effects of conservation and management of cultural and natural heritage in quality of life (Naidoo \& Sharpley, 2016; Tranter et al., 2017). It bases on a total of six indicators: as well as how necessary is good management of cultural and natural resources to enhance the present and future of population; the feedback about tourist-resident interaction and the responsibility about protecting cultural and natural heritage.

G-WELLB analyzes how tourism affects the political situation and the services provided to citizens (Buitrago et al., 2018; Ram, 2018). This dimension contains a total of four items: discrimination to access certain social services; corruption perception and trust in politicians; and enhancement of public services due to tourism.

The respondents had to indicate their level of agreement with each one of the items using a 5-point Likert scale where $1=$ completely disagree and $5=$ completely agree .

Finally, the questionnaire includes some questions related to the sociodemographic profile of residents (genre; civil status; age; academic level, and total annual earnings).

The questionnaires were previously pre-tested and reviewed by the Universidad Tecnológica de Santiago, in Santiago de los Caballeros, Dominican Republic.

A total of 287 questionnaires were obtained to be analyzed through the PLS-SEM technique. The size of the sample is bigger than 100, and thus, surpass the minimum recommended to apply this technique (Hair et al., 2016).

This sample combines people of different activities directly involved in tourism like hotels, food and beverages, handicrafts and souvenirs, as well as tours, guiding, and other activities.

The quotation sampling technique was applied (Sarstedt et al., 2018) to assure that the different groups (quotas) of the population were represented in the sample in the same proportion that they were found in the population (Carneiro et al., 2018). 


\subsection{Data treatment}

The collected questionnaires were treated through the PLS-SEM algorithm to test the four hypotheses or relations initially stated: H1) E-WELLB à M-WELLB; H2) M-WELLB à COM-WELLB; H3) COM- WELLB à CN-WELLB; and H4) G-WELLB à E-WELLB.

The PLS-SEM model is based on a reflective approach (Mode $B$ ), as the indicators in every one of the five constructs are the mean to measure these very constructs (Chea et al., 2018). Thus, the analysis requires being divided into two different stages: measurement model and structural model. The first one involves the outer part of the model (Lohmoller, 1988) that describes the relationships among the latent variables and their indicators. The second one, also known as the inner part of the model (Hair et al., 2016) represents the relationships between latent variables or constructs.

\subsection{Limitations}

One of the main weakness of the PLS-SEM technique is based on smaller samples than other methodologies. Additionally, this kind of technique is based on close-ended questions that can only be answered by selecting from a limited number of options. Thus, the obtained information from the questionnaire is more implicit than others tools such as an interview.

Regarding the different models of wellbeing, the literature is still debated (Dwyer, 2020) the indicators included in each dimension, as quality of life consists of a complex system containing a high number of interrelated indicators.

Furthermore, the results of this research must be taken into account as a

\section{RESULTS}

A total of 287 questionnaires were applied around 10 tourist places along the island mixing a total of three tourism modalities: natural, sun-and-sea, and cultural tourism-based destinations during the period January-May 2019. After this, questionnaires were analyzed according to the profile of the respondents and the constructs contained in the measurement and structural models tested in this research.

\subsection{Sample profile}

The total amount of collected questionnaires was 287. As shown in Table 1:

- $64.5 \%$ of respondents were male and $35.5 \%$ were female. Concerning their civil status, $62 \%$ were married and $38 \%$ were single. None of them reported being divorced or widowed.

- $35.2 \%$ of respondents were between $18-25$ years; $33.4 \%$ were between $26-34$ years; $10.5 \%$ were between $35-44$ years; $17.4 \%$ were between $45-54$ years and 3.5\% were between $55-64$ years old. None of the respondents were older than 65 years. Thus, young respondents predominate significantly over elder people in the tourism sector.

According to their academic level, $66.7 \%$ of the respondents were studying or holding a degree. $24.1 \%$ of the sample has secondary education and $9.2 \%$ stopped studying after primary school. This means that superior education is remarkably high among the respondents of the sample.

Regarding the level of annual earnings, most of the tourism professionals contained in the sample have low levels of annual income. $42.5 \%$ and $41.4 \%$ earn less than 10,000 DOP or between 10,001-20,000 DOP respectively per annum. Additionally, 13.8\% have incomes between 20,0001-30,000 DOP and 2.3\% earn more than 30,000 DOP. 
A total of four subsectors were represented in the collected questionnaires: $34.5 \%$ of respondents were from tours, visits and others; $25.8 \%$ were from hotels, $21.2 \%$ from food \& beverages and $18.5 \%$ were from handicrafts and souvenirs.

Table 1. Profile of respondents.

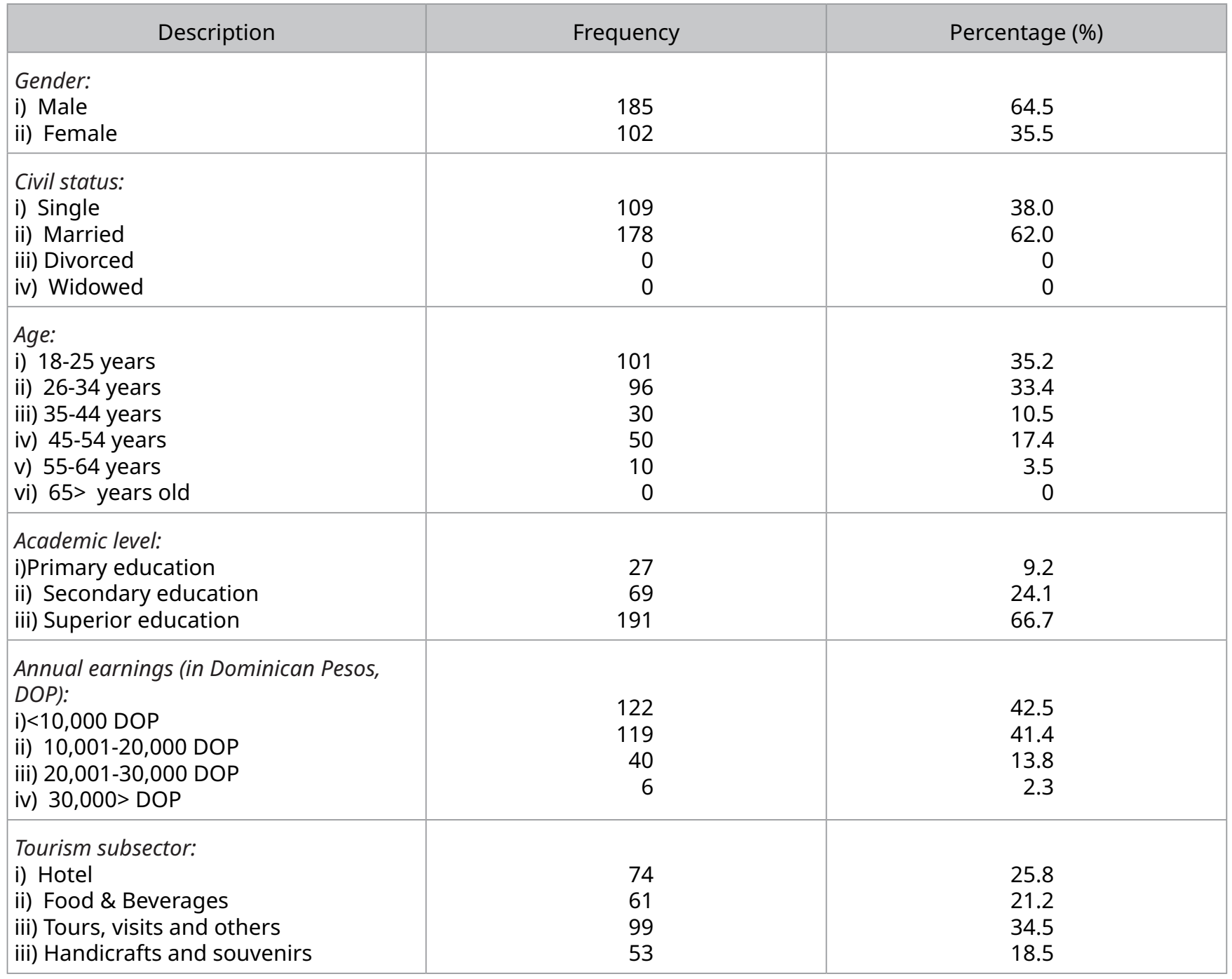

Source: Own elaboration

\subsection{Measurement model}

First, it was confirmed that the PLS-SEM algorithm achieved convergence at 35 iterations, so it does not exceed the maximum of 300 iterations (Ringle et al., 2013).

As a reflective model (Mode $A$ ), the measurement model was analyzed according to convergent validity, internal consistency reliability, and discriminant validity (Chea et al., 2018; Chin, 2010). Table 2 shows a summary of the results for this:

Convergent validity (Hair et al., 2016) was analyzed according to outer loadings and Average Variance Extracted (AVE).

All outer loadings of the reflective constructs should be above 0.70 to confirm their belonging to their corresponding construct (Hair et al., 2017). However, items with loads $0.40>$ and $<0.70$ were retained in the model, after checking AVE and Composite Reliability (CR) did not increase (Hulland, 1999). 
Table 2. Summary of results for the measurement model.

\begin{tabular}{|c|c|c|c|c|c|c|}
\hline \multirow{2}{*}{$\begin{array}{c}\text { Latent } \\
\text { variable }\end{array}$} & \multirow[b]{2}{*}{ Indicators } & \multicolumn{2}{|c|}{ Convergent validity } & \multicolumn{2}{|c|}{ Internal consistency reliability } & \multirow{2}{*}{\begin{tabular}{|}
$\begin{array}{c}\text { Discriminant } \\
\text { validity }\end{array}$ \\
Confidence \\
intervals of \\
HTMT do not \\
include value 1
\end{tabular}} \\
\hline & & $\begin{array}{c}\text { Outer } \\
\text { loading }\end{array}$ & AVE & CR & $\begin{array}{l}\text { Cronbach's } \\
\text { Alpha }\end{array}$ & \\
\hline 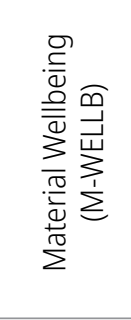 & $\begin{array}{l}\text { Coverage of basic needs } \\
\text { Access to a decent house } \\
\text { Acquisition of normal/luxury goods } \\
\text { Tourism effects on personal incomes } \\
\text { Tourism effects on costs of food } \\
\text { Tourism effects on costs of housing } \\
\text { Tourism effects on costs of clothing } \\
\text { Stability of the job }\end{array}$ & $\begin{array}{l}0.498 \\
0.678 \\
0.581 \\
0.648 \\
0.623 \\
0.506 \\
0.674 \\
0.586\end{array}$ & 0.522 & 0.788 & 0.704 & Yes \\
\hline 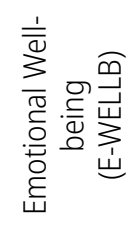 & $\begin{array}{l}\text { Access to a decent level of life } \\
\text { Own life standard versus other's } \\
\text { Quality and quantity of free time } \\
\text { Access to education } \\
\text { Satisfaction with current job } \\
\text { Level of happiness }\end{array}$ & $\begin{array}{l}0.719 \\
0.746 \\
0.754 \\
0.637 \\
0.732 \\
0.706\end{array}$ & 0.592 & 0.852 & 0.794 & Yes \\
\hline 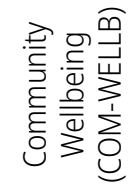 & $\begin{array}{l}\text { Enhancement of the environment } \\
\text { Transport infrastructure and accessibility } \\
\text { General employment opportunities }\end{array}$ & $\begin{array}{l}0.785 \\
0.807 \\
0.829\end{array}$ & 0.652 & 0.849 & 0.733 & Yes \\
\hline 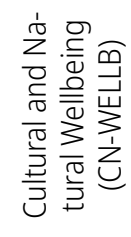 & $\begin{array}{l}\text { Satisfaction of contact with tourists } \\
\text { Tourism and natural areas protection } \\
\text { Tourism \& cultural areas protection } \\
\text { Responsibility heritage protection } \\
\text { Tourism and identity signs } \\
\text { Tourism future in line with community }\end{array}$ & $\begin{array}{l}0.724 \\
0.728 \\
0.659 \\
0.675 \\
0.655 \\
0.653\end{array}$ & 0.522 & 0.814 & 0.732 & Yes \\
\hline 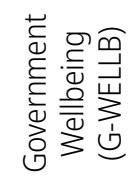 & $\begin{array}{l}\text { Public and community services } \\
\text { Trust in political authorities } \\
\text { Corruption } \\
\text { Access to public grants and benefits }\end{array}$ & $\begin{array}{l}0.779 \\
0.626 \\
0.782 \\
0.731\end{array}$ & 0.536 & 0.821 & 0.748 & Yes \\
\hline
\end{tabular}

Source: Own elaboration

Convergent validity (Hair et al., 2016) was analyzed according to outer loadings and Average Variance Extracted (AVE).

All outer loadings of the reflective constructs should be above 0.70 to confirm their belonging to their corresponding construct (Hair et al., 2017). However, items with loads $0.40>$ and $<0.70$ were retained in the model, after checking AVE and Composite Reliability (CR) did not increase (Hulland, 1999).

The AVE values are above 0.5, which means that the construct explains more than half of the variance of its indicators, concluding convergent validity (Chin, 2010).

Internal consistency reliability is assessed using Cronbach's Alpha and composite CR (Hair et al., 2017). While Cronbach's alpha tends to underestimate the internal consistency reliability, the CR overestimates them, thus it is appropriate to consider both indicators.

According to Cronbach's Alpha, all constructs show values above 0.70 (Aibinu et al., 2010). Regarding CR, all constructs show values above 0.70 , which implies that they have high levels of internal consistency reliability. On the other hand, no value is higher than 0.90 , that means that none of the variables measure the same aspect and thus, there are not redundant constructs (Hayduk \& Littvay, 2012). 
To test discriminant validity, Heterotrait-Monotrait (HTMT) ratio of correlations was approached. All HTMT values are lower than 0.85 for all construct pairs. In addition to this, Bootstrap confidence intervals were calculated from 5,000 subsamples to confirm that none of the confidence intervals include the value 1.

The results of analyzing the measurement model confirm that all evaluation criteria are valid and that constructs and indicators must be included in the nomogram.

\subsection{Structural model}

The structural model represents hypothetical-conceptual relations that are underlying in the nomogram, as it evaluates the weight and magnitude of these relationships (Melchor \& Julián, 2008).

First of all, Variance Inflation Factors (VIF) of all predictive constructs were examined to detect any collinearity problem: H1) E-WELLB as a predictor of M-WELLB $(V I F=1) ; \mathrm{H} 2)$ M-WELLB as a predictor of COM-WELLB $(V I F=1)$; H3) COM-WELLB as a predictor of CN-WELLB $(V I F=1)$; and H4) G-WELLB as a predictor of E-WELLB $(V I F=1)$. Thus, there are no collinearity problems, as none of these relations have a VIF higher than 5 (Benítez et al., 2020).

To evaluate the predictive power of the proposed model (Figure 2), goodness of fit of the variables $\left(R^{2}\right)$ and Stone-Geisser's criterion $\left(Q^{2}\right)$ were observed (Geisser, 1975; Stone, 1974). Chin (1998) established that $R^{2}$ measures of $0.67,0.33$, and 0.19 should be classified as substantial, moderate, and weak, respectively. However, the values of $\mathrm{R}^{2}$ vary according to the complexity of the model and the research discipline (Hair et al., 2016).

In the case of the structural relationship between tourism and quality of life, the number of works is limited. Thus, there is a lack of consensus about the predictive power of constructs used in these models, accepting values below 0.089 (Koshkam et al., 2016; Rasoolimanesh et al., 2017).

In this model, the $R^{2}$ values of the endogenous constructs are 0.177 for M-WELLB; 0.152 for COM-WELLB; 0.396 for CN-WELLB, and 0.100 for E-WELLB (Figure 2). Furthermore, since $\mathrm{Q}^{2}>0$ for all constructs, the model has an acceptable prediction power, establishing the predictive importance of all the endogenous constructs in the model (Benítez et al., 2020).

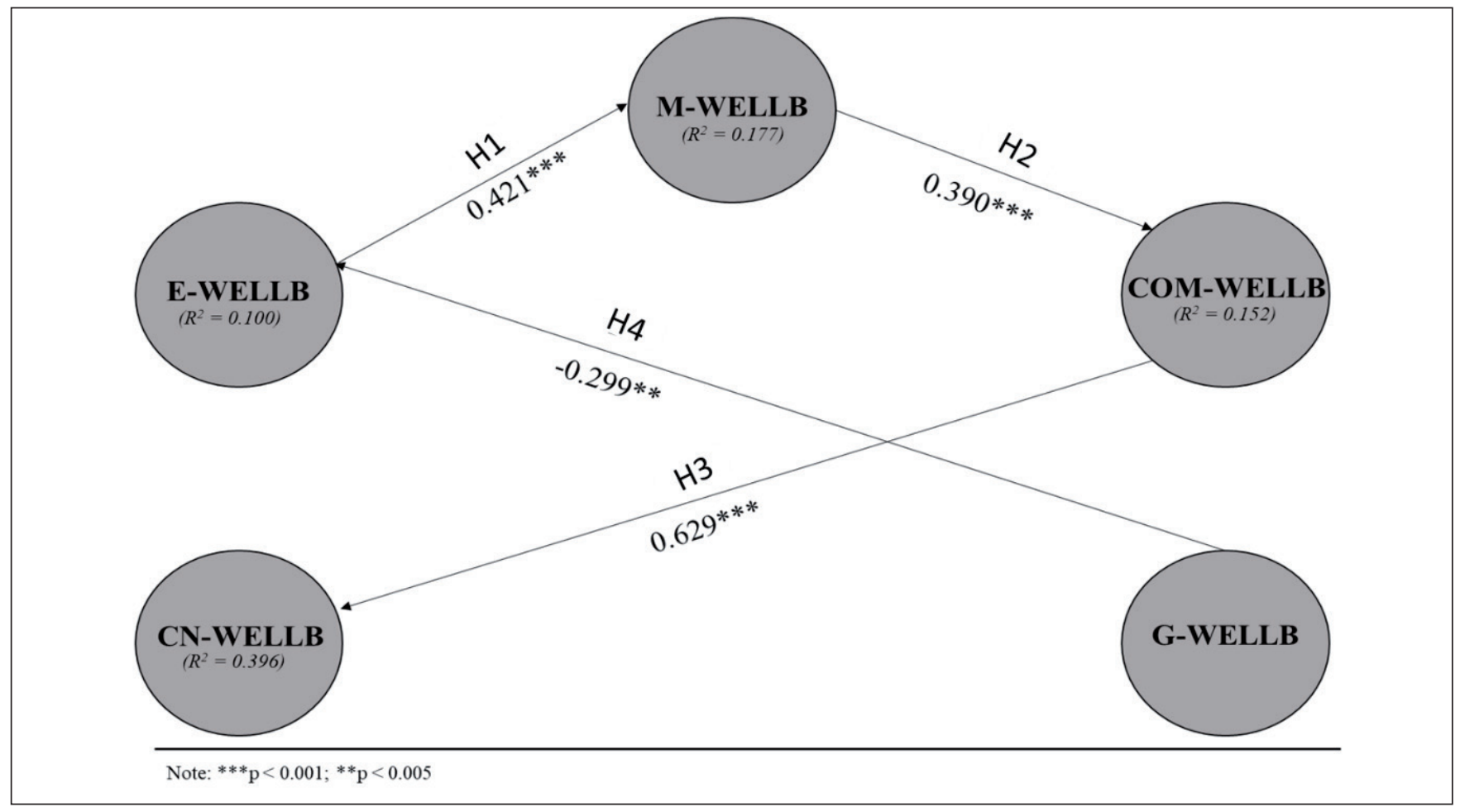

Figure 2. Hypothetical-conceptual model. Source: Own elaboration 
Table 3 sets out the contrast of the proposed hypotheses according to the level of significance of the bootstrap test, including the path coefficients and the $t$ values (Hair et al., 2017).

Table 3. Model path coefficients of SEM and hypotheses test results.

\begin{tabular}{|c|l|c|c|c|}
\hline Hypotheses $\beta$ & \multicolumn{1}{|c|}{ Influence path } & Path coefficients & t value & Results \\
\hline H1 & E-WELLB $\rightarrow$ M-WELLB & $0.421 * * *$ & 4.796 & Supported \\
H2 & M-WELLB $\rightarrow$ COM-WELLB & $0.390 * * *$ & 4.263 & Supported \\
H3 & COM-WELLB $\rightarrow$ CN-WELLB & $0.629 * * *$ & 9.845 & Supported \\
H4 & G-WELLB $\rightarrow$ E-WELLB & $-0.299 * *$ & 2.831 & Unsupported \\
\hline
\end{tabular}

Note: ${ }^{* * *} \mathrm{p}<0.001 ;{ }^{* *} \mathrm{p}<0.005$

Source: Own elaboration

The support of $\mathrm{H} 1$ ( $\beta=0.421, \rho=0.000$ ) confirms that emotional wellbeing is the cause of material wellbeing.

The results support $\mathrm{H} 2(\beta=0.390, \rho=0.000)$, suggesting that the bigger the material benefits derived from tourism are, the larger these benefits are materialized and perceived among the whole community members. Likewise, regarding $\mathrm{H} 3(\beta=0.629, \rho=0.000)$, as these community benefits from tourism increase, it also does the protection and promotion of cultural and natural resources in the community that contributes to enforcing the feeling of community belonging.

Finally, the current political situation, as well as the (in)accessibility to public benefits and services, seems to deteriorate the emotional wellbeing of the population. Thus, $H 4(\beta=-0.299, \rho=0.002)$ is unsupported.

\section{DISCUSSION}

\subsection{Materialism does not buy happiness and good emotions}

According to the findings of this research, $\mathrm{H} 1$ suggests that the Dominican model of individual happiness is not based on material goods but emotions, and thus, greed is considered a poverty condition among rich people as other authors suggest (Rivera et al., 2016).

Respondents of the questionnaire suggested that the single fact of having a new day on the Earth is a "blessing" and they felt thankful for having food, time to share with family and friends, as well as a bed to sleep (White, 2010).

The future plans become for Dominican respondents a means of procrastinating happiness. This does not mean that life plans are unsuitable for happiness, but a reason for focusing on the trail and not on the result itself (Kafashpor et al., 2018). The Dominican is not so happy in as much as he possesses more goods, but in sharing vital experiences with his environment, which enriches his life. For the case of tourism, the friendly and near character of the Dominican with the tourist is the reflection of its attitude with life.

In contrast to this subjective point of view, most of the respondents indicated that they were in a salary range of 10,000-15,000 Dominican pesos (\$200-250). However, according to data from the country's Ministry of Labor (2018), the cost of living is considerably higher, where only the basic food basket is approximately 29,000 Dominican pesos (\$600).

In summary, tourism is presented as a phenomenon with a "therapeutic" effect for people who are dedicated to this activity, to the extent that it allows them to have a relationship with the tourist, in a sector associated with leisure, fun, and memorable experiences.

\subsection{The measure of who we are is what we do with what we have}

The previous postulate of Dominican model of happiness is just the contrary for the case of community material goods possessed. 
Concerning $\mathrm{H} 2$ and $\mathrm{H} 3$, having more is having more to share with. Thus, the material dimension acquires a meaning of wellbeing when it is for enhancing the quality of life for the rest of the members of the community, in line with the findings of other authors (Biswas-Diener et al.; Pratt et al., 2016).

Community wellbeing is made by the set of interrelations made across the members via tangible assets remarking two attributes:

- On one hand, as stated in $\mathrm{H} 2$, the dynamic side of wellbeing is built by the redistribution of material goods and resources among the community with the function of reducing inequalities and contributing to a general situation of welfare at the community level (Surugiu \& Surugiu, 2013).

- On the other hand, $\mathrm{H} 3$ suggests that the condition of wellbeing in a community is static or stable due to the cultural and natural resources that build the identity signs of the community. This heritage is not only a symbol and an identification to reinforce the feeling of belongingness but also a reason to protect and manage a series of tangible and intangible assets with several purposes agreed-upon community members (Crooke, 2010).

To synthesize, the aparigraha principle of Gandhi exists among Dominican regarding individual wellbeing, but it turns into a contrary attitude of "greed" as a means of survival as a community and enhancing welfare conditions of the members.

\subsection{The care of human life and happiness: the first and only object of good government?}

Thomas Jefferson stated that "the care of human life and happiness, and not their destruction, is the first and only object of good government".

According to $\mathrm{H} 4$, it is observed that the public sector continues to be the object of mistrust among Dominican population, without covering their expectations in terms of justice administration or reliability on political leaders, despite perceiving the political environment as stable (Walton, 2013).

This very feeling of belonging of community is altered regarding community at supra-municipal level, and thus, community wellbeing decreases, as members may feel betrayed by other members of the community (political leaders responsible for "common welfare") (Melgar et al., 2010).

Furthermore, regarding the importance of tourism in Dominican Republic, there is a high number of foreign actors investing in a large number of tourism projects with annual investments of up to 700 million dollars a year (Dominican Central Bank, 2017). This implies that foreign stakeholders have important decision-making power on issues that directly affect community members.

\section{CONCLUSION}

A hypothetical conceptual model has been tested according to the perception of the quality of life that tourism brings to Dominican population to uncover the Caribbean model of happiness. PLS-SEM was the technique used to test this hypothetical conceptual model. These findings are also useful for contrasting the tested model of happiness with others models worldwide and identifying more links between tourism and resident's wellbeing.

First of all, the findings of the measurement model of this research confirm that all the constructs included in the model are significant in the Dominican model of wellbeing: 1) M-WELLB; 2) E-WELLB; 3) CN-WELLB; 4) COM-WELLB; and 5) G-WELLB.

$\mathrm{H} 1$ was supported suggesting that emotional wellbeing has a direct effect on material wellbeing. This implies the Dominican population is not prevented from living happily and joyfully despite being in a situation of material deprivation.

However, $\mathrm{H} 2$ suggests that materialistic attitudes exist among the Dominican population regarding any material good that contributes to an increase in the general welfare conditions of community members, as well as reduce existing inequalities. 
$\mathrm{H} 3$ confirms that cultural and natural heritage contributes to building the belonging feelings among community members that is a crucial construct to determine the individual's emotional wellbeing.

Finally, $\mathrm{H} 4$ suggests that government influences in a negative way on the emotional wellbeing of Dominican individuals, as political actions are not perceived as the "best way" to assure general welfare in society.

The social policies of Dominican authorities should combine an emotional and material approach to assure that wellbeing is increased.

It is also necessary to evaluate the material and emotional situation of the Dominican population to identify deprivations that may have not been identified by Dominican residents but need to be covered.

Political leaders must become trustful for the population so that political decisions can contribute to enhancing the emotional wellbeing of the population.

In conclusion, future lines of research should focus on identifying additional constructs and indicators associated with Dominican model of wellbeing as a means to test that poverty is not "romanticized" as a form of false happiness. Furthermore, more and different indicators and dimensions should be considered in the analyzed wellbeing models, as a dynamic and complex interrelated system (Dwyer, 2020).

\section{Acknowledgments}

This research was funded by the Iberoamerican University Association of Postgraduate Studies.

\section{Conflicts of interest and authorship statement}

The author undertakes to disclose any existing or potential conflict of interest in relation to the publication of their article

\section{REFERENCES}

Andereck, K.L. \& Nyaupane, G. P. (2011). Exploring the nature of tourism and quality of life perceptions among residents. Journal of Travel Research, 50(3), 248-260. https://doi.org/10.1177/0047287510362918

Aref, F. (2011). The effects of tourism on quality of life: A Case Study of Shiraz, Iran. Life Science Journal, 8(2), 26-30.

Atkinson, S., Bagnall, A.M., Corcoran, R., South, J. \& Curtis, S. (2020). Being well together: individual subjective and community wellbeing. Journal of Happiness Studies, 21(5), 1903-1921. https://doi.org/10.1007/s10902-019-00146-2

Atkinson, S. \& Joyce, K.E. (2011). The place and practices of well-being in local governance. Environment and Planning C: Government and Policy, 29(1), 133-148. https://doi.org/10.1068/c09200

Basole, A. (2005). The economics of ahimsa: Gandhi, Kumarappa, and the non-modern challenge to economics.

Bedran-Martins, A.M., Lemos, M.C. \& Philippi, A. (2018). Relationship between subjective well-being and material quality of life in face of climate vulnerability in NE Brazil. Climatic Change, 147(1-2), 283-297. https://doi.org/10.1007/ s10584-017-2105-y

Benitez, J., Henseler, J., Castillo, A. \& Schuberth, F. (2020). How to perform and report an impactful analysis using partial least squares: guidelines for confirmatory and explanatory IS research. Information \& Management, 57(2), 103168. https://doi.org/10.1016/j.im.2019.05.003

Bennett, N.J. \& Dearden, P. (2014). Why local people do not support conservation: Community perceptions of marine protected area livelihood impacts, governance and management in Thailand. Marine policy, (44), 107-116. https:// doi.org/10.1016/j.marpol.2013.08.017

Buitrago, E.M., Caraballo, M.A. \& Roldán J.L. (2018). Do Tolerant Societies Demand Better Institutions? Social Indicators Research, 1-24.

Buzinde, C.N., Kalavar, J.M. \& Melubo, K. (2014). Tourism and community well-being: The case of the Maasai in Tanzania. Annals of Tourism Research, 44, 20-35. https://doi.org/10.1016/j.annals.2013.08.010 
Carneiro, M.J., Eusébio, C. \& Caldeira, A. (2018). The influence of social contact in residents' perceptions of the tourism impact on their quality of life: A structural equation model. Journal of Quality Assurance in Hospitality \& Tourism, 19(1), 1-30. https://doi.org/10.1080/1528008X.2017.1314798

Chan, C., Armitage, D., Alexander, S.M. \& Campbell, D. (2019). Examining linkages between ecosystem services and social wellbeing to improve governance for coastal conservation in Jamaica. Ecosystem Services, (39), 100997. https://doi. org/10.1016/j.ecoser.2019.100997

Cheah, J.H., Memon, M.A., Chuah, F., Ting, H. \& Ramayah, T. (2018). Assessing reflective models in marketing research: A comparison between pls and plsc estimates. International Journal of Business and Society, 19(1), 139-160.

Chin, W.W. (1998). The partial least squares approach for structural equation modeling. In G. Marcoulides (ed.), Modern methods for business research (pp. 295-336). Lawrence Erlbaum Associates.

Chin, W.W. (2010). How to write up and report PLS analyses. In Handbook of partial least squares (pp. 655-690). Springer. https://doi.org/10.1007/978-3-540-32827-8_29

Cho, E.Y.N. (2018). Links between poverty and children's subjective wellbeing: Examining the mediating and moderating role of relationships. Child Indicators Research, 11(2), 585-607. https://doi.org/10.1007/s12187-017-9453-z

Cloutier, S., Ehlenz, M.M. \& Afinowich, R. (2019). Cultivating Community Wellbeing: Guiding Principles for Research and Practice. International Journal of Community Well-Being, 2(3-4), 277-299. https://doi.org/10.1007/s42413-019-00033-X

Cohen, E., Ware, L.J., Prioreschi, A., Draper, C., Bosire, E., Lye, S. J. \& Norris, S. A. (2020). Material and Relational Difficulties: The Impact of the Household Environment on the Emotional Well-Being of Young Black Women Living in Soweto, South Africa. Journal of Family Issues, 41(8), 1307-1332. https://doi.org/10.1177/0192513X19887524

Croes, R., Rivera, M., Pizam, A., Olson, E., Lee, S. \& Zhong, Y. (2011). Winning the Future: Strategic Plan for the Development of Tourism. Dick Pope Sr. Institute Publications, (34).

Croes, R., Ridderstaat, J. \& van Niekerk, M. (2018). Connecting quality of life, tourism specialization, and economic growth in small island destinations: The case of Malta. Tourism Management, (65), 212-223. https://doi.org/10.1016/j.tourman.2017.10.010

Crooke, E. (2010). The politics of community heritage: motivations, authority and control. International Journal of Heritage Studies, 16(1-2), 16-29. https://doi.org/10.1080/13527250903441705

Di Tella, R. \& MacCulloch, R. (2008). Gross national happiness as an answer to the Easterlin Paradox? Journal of Development Economics, 86(1), 22-42. https://doi.org/10.1016/j.jdeveco.2007.06.008

Dominican Central Bank (2018). Importancia y evolución del turismo en la República Dominicana, 2012-2017. Santo Domingo: República Dominicana.

Dwyer, L. (2020). Tourism development and sustainable well-being: A Beyond GDP perspective. Journal of Sustainable Tourism, 1-18. https://doi.org/10.1080/09669582.2020.1825457

Easterlin, R. A. (1995). Will raising the incomes of all increase the happiness of all? Journal of Economic Behavior \& Organization, 27(1), 35-47. https://doi.org/10.1016/0167-2681(95)00003-B

Frijters, P., Clark, A.E., Krekel, C. \& Layard, R. (2020). A happy choice: wellbeing as the goal of government. Behavioural Public Policy, 4(2), 126-165. https://doi.org/10.1017/bpp.2019.39

Geisser, S. (1975). The predictive sample reuse method with applications. Journal of the American Statistical Association, 70(350), 320-328. https://doi.org/10.1080/01621459.1975.10479865

Gillam, C. \& Charles, A. (2019). Community wellbeing: The impacts of inequality, racism and environment on a Brazilian coastal slum. World Development Perspectives, 13, 18-24. https://doi.org/10.1016/j.wdp.2019.02.006

Gollan, N., Voyer, M., Jordan, A. \& Barclay, K. (2019). Maximising community wellbeing: Assessing the threats to the benefits communities derive from the marine estate. Ocean \& Coastal Management, (168), 12-21. https://doi.org/10.1016/j.ocecoaman.2018.10.020

Gross-Manos, D. (2017). Material well-being and social exclusion association with children's subjective Well-being: Cross-national analysis of 14 countries. Children and Youth Services Review, (80), 116-128. https://doi.org/10.1016/j. childyouth.2017.06.048

Hair, J. F., Ringle, C. M. \& Sarstedt, M. (2011). PLS-SEM: Indeed a silver bullet. Journal of Marketing theory and Practice, 19(2), 139-152. https://doi.org/10.2753/MTP1069-6679190202

Hair Jr, J.F., Hult, G.T.M., Ringle, C. \& Sarstedt, M. (2016). A primer on partial least squares structural equation modeling (PLSSEM). Sage publications. https://doi.org/10.15358/9783800653614 
Hair Jr, J.F., Matthews, L.M., Matthews, R.L. \& Sarstedt, M. (2017). PLS-SEM or CB-SEM: updated guidelines on which method to use. International Journal of Multivariate Data Analysis, 1(2), 107-123. https://doi.org/10.1504/IJMDA.2017.087624

Hayduk, L.A. \& Littvay, L. (2012). Should researchers use single indicators, best indicators, or multiple indicators in structural equation models? BMC medical research methodology, 12(1), 159. https://doi.org/10.1186/1471-2288-12-159

Holmes, M. \& McKenzie, J. (2019). Relational happiness through recognition and redistribution: Emotion and inequality. European Journal of Social Theory, 22(4), 439-457. https://doi.org/10.1177/1368431018799257

Kafashpor, A., Ghasempour Ganji, S. F., Sadeghian, S. \& Johnson, L. W. (2018). Perception of tourism development and subjective happiness of residents in Mashhad, Iran. Asia Pacific Journal of Tourism Research, 23(6), 521-531. https:// doi.org/10.1080/10941665.2018.1476392

Kahneman, D. \& Deaton, A. (2010). High income improves evaluation of life but not emotional well-being. Proceedings of the national academy of sciences, 107(38), 16489-16493. https://doi.org/10.1073/pnas.1011492107

Khoshkam, M., Marzuki, A. \& Al-Mulali, U. (2016). Socio-demographic effects on Anzali wetland tourism development. Tourism Management, 54, 96-106. https://doi.org/10.1016/j.tourman.2015.10.012

Kim, P.S. (2008). A daunting task in Asia: The move for transparency and accountability in the Asian public sector. Public Management Review, 10(4), 527-537. https://doi.org/10.1080/14719030802263962

Kim, K., Uysal, M. \& Sirgy, M.J. (2013). How does tourism in a community impact the quality of life of community residents? Tourism management, 36, 527-540. https://doi.org/10.1016/j.tourman.2012.09.005

Landorf, C. (2009). Managing for sustainable tourism: a review of six cultural World Heritage Sites. Journal of Sustainable Tourism, 17(1), 53-70. https://doi.org/10.1080/09669580802159719

Lee, S.J. \& Kim, Y. (2016). Structure of well-being: An exploratory study of the distinction between individual well-being and community well-being and the importance of intersubjective community well-being. In Y. Kee, S.J. Lee \& R. Phillips (eds.), Social factors and community wellbeing (pp. 13-37). Springer. https://doi.org/10.1007/978-3-31929942-6_2

Li, S. \& Wu, J. (2010) Why some countries thrive despite corruption: The role of trust in the corruption- efficiency relationship. Review of International Political Economy, 17(1), 129-154. https://doi.org/10.1080/09692290802577446

Mathew, P.V. \& Sreejesh, S. (2017). Impact of responsible tourism on destination sustainability and quality of life of community in tourism destinations. Journal of Hospitality and Tourism Management, (31), 83-89. https://doi.org/10.1016/j. jhtm.2016.10.001

Melgar, N., Rossi, M. \& Smith, T.W. (2010). The perception of corruption. International Journal of Public Opinion Research, 22(1), 120-131. https://doi.org/10.1093/ijpor/edp058

Millán-Puelles, A. (1962). Persona humana y justicia social. Colección Estudios.

Ministry of Labor of the Dominican Republic (20120, 5 de junio) Datos básicos sobre el costo de la vida en República Dominicana. http://www.empleocard.info/republica-dominicana/costo-de-la-vida

Naidoo, P. \& Sharpley, R. (2016). Local perceptions of the relative contributions of enclave tourism and agritourism to community well-being: The case of Mauritius. Journal of Destination Marketing \& Management, 5(1), 16-25. https:// doi.org/10.1016/j.jdmm.2015.11.002

Nawijn, J. \& Mitas, O. (2012). Resident attitudes to tourism and their effect on subjective well-being: The case of Palma de Mallorca. Journal of Travel Research, 51(5), 531-541. https://doi.org/10.1177/0047287511426482

Oficina Nacional Estadística (ONE) (2020, $5^{\text {th }}$ March). Tourism data. https://www.one.gob.do/economicas/turismo.

Palmer, C. (1999). Tourism and the symbols of identity. Tourism management, 20(3), 313-321. https://doi.org/10.1016/ S0261-5177(98)00120-4

Papathanassis, A., Katsios, S. \& Dinu, N.R. (eds.) (2018). Yellow Tourism: Crime and Corruption in the Holiday Sector. Springer. https://doi.org/10.1007/978-3-319-94664-1

Phillips, T., Taylor, J., Narain, E. \& Chandler, P. (2021) Selling Authentic Happiness: Indigenous wellbeing and romanticised inequality in tourism advertising. Annals of Tourism Research, (87), 103115. https://doi.org/10.1016/j.annals.2020.103115

Power, A. \& Smyth, K. (2016). Heritage, health and place: The legacies of local community-based heritage conservation on social wellbeing. Health \& Place, (39), 160-167. https://doi.org/10.1016/j.healthplace.2016.04.005

Pratt, S., McCabe, S. \& Movono, A. (2016). Gross happiness of a'tourism'village in Fiji. Journal of Destination Marketing \& Management, 5(1), 26-35. https://doi.org/10.1016/j.jdmm.2015.11.001 
Ram, Y. (2018). Hostility or hospitality? A review on violence, bullying and sexual harassment in the tourism and hospitality industry. Current Issues in Tourism, 21(7), 760-774. https://doi.org/10.1080/13683500.2015.1064364

Rao, N. D. \& Min, J. (2018). Decent living standards: material prerequisites for human wellbeing. Social indicators research, 138(1), 225-244. https://doi.org/10.1007/s11205-017-1650-0

Rasoolimanesh, S.M., Ringle, C.M., Jaafar, M. \& Ramayah, T. (2017). Urban vs. rural destinations: Residents' perceptions, community participation and support for tourism development. Tourism Management, 60, 147-158. https://doi.org/10.1016/j.tourman.2016.11.019

Ridderstaat, J., Croes, R. \& Nijkamp, P. (2016). The tourism development-quality of life nexus in a small island destination. Journal of Travel Research, 55(1), 79-94. https://doi.org/10.1177/0047287514532372

Rigdon, E.E. (2012). Rethinking partial least squares path modeling: In praise of simple methods. Long Range Planning, 45(5-6), 341-358. https://doi.org/10.1016/j.Irp.2012.09.010

Ringle, C.M., Sarstedt, M., Schlittgen, R. \& Taylor, C.R. (2013). PLS path modeling and evolutionary segmentation. Journal of Business Research, 66(9), 1318-1324. https://doi.org/10.1016/j.jbusres.2012.02.031

Rivera, M., Croes, R. \& Lee, S.H. (2016). Tourism development and happiness: A residents' perspective. Journal of Destination Marketing \& Management, 5(1), 5-15. https://doi.org/10.1016/j.jdmm.2015.04.002

Sarriera, J.C., Casas, F., Bedin, L., Abs, D., Strelhow, M.R., Gross-Manos, D. \& Giger, J. (2015). Material resources and children's subjective well-being in eight countries. Child Indicators Research, 8(1), 199-209. https://doi.org/10.1007/ s12187-014-9284-0

Sarstedt, M., Bengart, P., Shaltoni, A.M. \& Lehmann, S. (2018). The use of sampling methods in advertising research: A gap between theory and practice. International Journal of Advertising, 37(4), 650-663. https://doi.org/10.1080/0265 0487.2017.1348329

Sharpley, R. \& Naidoo, P. (2010). Tourism and poverty reduction: The case of Mauritius. Tourism and Hospitality Planning \& Development, 7(2), 145-162. https://doi.org/10.1080/14790531003737169

Siddiqi, M. (2004). Shalish and the Quest for Gender Justice: An Assessment of Strategic Interventions in Bangladesh, Final Report, Dhaka: Research Initiatives Bangladesh.

Smith, M. \& Reisinger, Y. (2013). Transforming quality of life through wellness tourism. Transformational tourism: Tourist perspectives, 55-67. https://doi.org/10.1079/9781780642093.0055

Stone, M. (1974). Cross-validatory choice and assessment of statistical predictions. Journal of the Royal Statistical Society: Series B (Methodological), 36(2), 111-133. https://doi.org/10.1111/j.2517-6161.1974.tb00994.x

Su, M.M., Wall, G., \& Xu, K. (2016). Tourism-induced livelihood changes at mount Sanqingshan world heritage site, China. Environmental Management, 57(5), 1024-1040. https://doi.org/10.1007/s00267-016-0672-8

Surugiu, C. \& Surugiu, M.R. (2013). Is the tourism sector supportive of economic growth? Empirical evidence on Romanian tourism. Tourism Economics, 19(1), 115-132. https://doi.org/10.5367/te.2013.0196

Tranter, B., Lester, L. \& McGaurr, L. (2017). Indigenous Engagement: Three Case Studies. In Leadership and the Construction of Environmental Concern (pp. 117-150). Palgrave Macmillan. https://doi.org/10.1057/978-1-137-56584-6

UNWTO (2019). World Tourism Highlights 2018 Edition. Organización Mundial de Turismo.

Uysal, M. \& Modica, P. (2016). Island tourism: challenges and future research directions. Sustainable Island Tourism: Competitiveness and Quality of Life, 173-188. https://doi.org/10.1079/9781780645421.0173

Uysal, M., Sirgy, M.J., Woo, E. \& Kim, H.L. (2016). Quality of life (QOL) and well-being research in tourism. Tourism Management, (53), 244-261. https://doi.org/10.1016/j.tourman.2015.07.013

Vogt, C., Jordan, E., Grewe, N. \& Kruger, L. (2016). Collaborative tourism planning and subjective well-being in a small island destination. Journal of Destination Marketing \& Management, 5(1), 36-43. https://doi.org/10.1016/j.jdmm.2015.11.008

Walton, G.W. (2013). Is all corruption dysfunctional? Perceptions of corruption and its consequences in Papua New Guinea. Public Administration and Development, 33(3), 175-190. https://doi.org/10.1002/pad.1636

White, S.C. (2010). Analysing wellbeing: A framework for development practice. Development in practice, 20(2), $158-172$. https://doi.org/10.1080/09614520903564199

World Health Organisation (2020, 4th December). Measuring Quality of Life. https://www.who.int/healthinfo/survey/whoqol-qualityoflife/en/ 